Chapter 4

\title{
The role of the winds in architectural theory from
}

\section{Vitruvius to Scamozzi}

Alessandro Nova

Plain common sense suggests that we should live in clean, healthy and safe environments. Thus, all architectural treatises from the time of Vitruvius onwards discuss in greater or lesser detail where we should found our cities, and observe that the climate should be temperate, the air not too hot and not too cold, the winds fresh and that they should be in regions of abundant water supply. The disarming simplicity of these Hippocratic requirements needs no specific comment, or so it seems. Yet we should ask ourselves why Vitruvius and many architects who came after him invested so much energy in discussing these matters if they are obvious or irrelevant.

A first answer is that the winds have always played a major role in people's lives, physically as well as metaphorically: humans live and build their institutions on terra firma, but the metaphor of their troubled destinies fulfills itself completely only on the open sea, where our boat sails with and against the unpredictable capricious force of the winds. The threat of shipwreck and the hope represented by the harbor resurface periodically as images of mortal danger and salvation in western art, literature and philosophy, from Homer and Lucretius to Voltaire and Schopenhauer. ${ }^{2}$

A second reason for an abiding fascination with the winds was their ambiguous status: different theories existed about their origin; nobody knew exactly where they came from or how they moved in the sublunary world; ${ }^{3}$ 
furthermore, they had and still have benign as well as harmful effects upon our existence. Their double character and irregular movement had always been a problem for those who sought to systematize the order of nature: because of their unpredictability, it was difficult to find a place for them within any accepted cosmological model, as the lack of clarity in Aristotle's Meteorology shows. ${ }^{4}$

This is perhaps enough to explain Vitruvius's interest in the winds. No less baffling, however, is the reception that Vitruvius's excerpts concerning this phenomenon received in the commentaries of the Early Modern period. In spite of the fact that other passages of his treatise were often discussed in a more or less straightforward way, the intensity and thoroughness of the responses of various commentators - from Cesare Cesariano ${ }^{5}$ to Daniele Barbaro ${ }^{6}$ - on the issue of winds remains astonishing. The truth is that the debate on air and winds reflects important changes in our view of the world and, to a lesser extent, in the conceptualization of the ideal city. The variety of available sources is daunting. Although this chapter's observations will concentrate on Vitruvius, Alberti and Scamozzi, this is neither to say that they cover all aspects of the complex relationship between the winds and the city nor that their texts can be used to illustrate a sort of "progress" or development in this story. My aim in this chapter is to analyze their very different approaches to the same issue.

So far as Vitruvius is concerned, we should reconcile his focus on architectural praxis with his implicit cosmographical interests. Alberti's discussion of the winds was instead related to an ambitious project designed to create a new urban science in the service of a community governed by an oligarchy. Scamozzi exemplifies well the interests of a new world which was better informed about the shape of the earth and the cosmos as well as about natural phenomena. His empiricism was a weapon against obsolete geographies and a shield for potentially dangerous cosmographies.

The main thesis of this chapter is, therefore, the following: even if Vitruvius, Alberti and Scamozzi address the same issues and sometimes make similar points concerning the relationship between the winds and the city, their perspectives are irreconcilable. Vitruvius represents the views of a pre-Christian world, Alberti expresses the aspirations of post-medieval humanism, and Scamozzi documents the knowledge of a society which has discovered the New World and is enrolled in the debates triggered by Galileo's Istoria e dimostrazioni intorno alle macchie solari e loro accidenti (1613), with all the cultural implications that such events entail.

The locus classicus on the orientation of the city's lanes in relation to the blowing winds is of course chapter six of Vitruvius's first book, which I quote in abridged form from Ingrid Rowland's translation:

Once the walls have been raised, the division into lots of the area contained within the walls should follow, and the orientation of the streets and lanes 
according to the regions of the heavens. [Moenibus circundatis secuntur intra murum arearum divisiones platearumque et angiportuum ad caeli regionem (or regiones) directiones.] This process will be properly accomplished if, with foresight, the lanes are kept from facing into the path of the prevailing winds. For if the winds are cold, they injure; if hot, they corrupt; if moist, they are noxious. ... Mild, dense air, which has neither drafts nor frequent circulation, on account of its motionless stability, by adding to the physique of those who are afflicted with these diseases, nourishes [instead] the patients and restores them to health.... Then it will be evident that the alignment of the streets and side streets ought to follow the angles between the regions of two different winds [emphasis mine].

By means of these principles and these divisions, the detrimental force of the winds will be shut out of dwellings and side streets, for when the broad streets are designed to face the winds head on, the force and the dense gusts coming from the open expanse of the heavens, trapped in the heads of alleyways, wander about with more violent energy. For these reasons the orientation of streets should be rotated obliquely to the regions of the winds [emphasis mine]; then, when the gusts approach the corners of apartment blocks they break apart, and, repulsed, are dissipated. ${ }^{7}$

After a long passage in which Vitruvius explains, in detail, with the help of a lost drawing like the one here reproduced as Figure 4.1, how one should construct a wind-rose - which, incidentally, is a sixteenth-century term - he ends his chapter with the following observation: when one has established the positions of the eight principal winds, one can carry out the division of the side streets by putting a square between the corners of the resulting octagon. ${ }^{8}$

We must underline three points of this well-known Vitruvian text:

1 Vitruvius implies a correspondence or at least a relationship between micro- and macrocosm when he writes that the orientation of the streets and lanes must be fixed taking into account the regions of the heavens, above all when we consider that his text is not only concerned with the sublunary world.

2 The orientation of the streets and side lanes ought to follow the angles between the regions of two different winds, that is the orientation of the streets should be rotated obliquely to the regions of the eight principal winds.

3 The reason for this rotation is related to erroneous physiological assumptions since, in opposition to Aristotle and others, Vitruvius thinks that all winds are bad for our health and that stagnant air favors good health. 

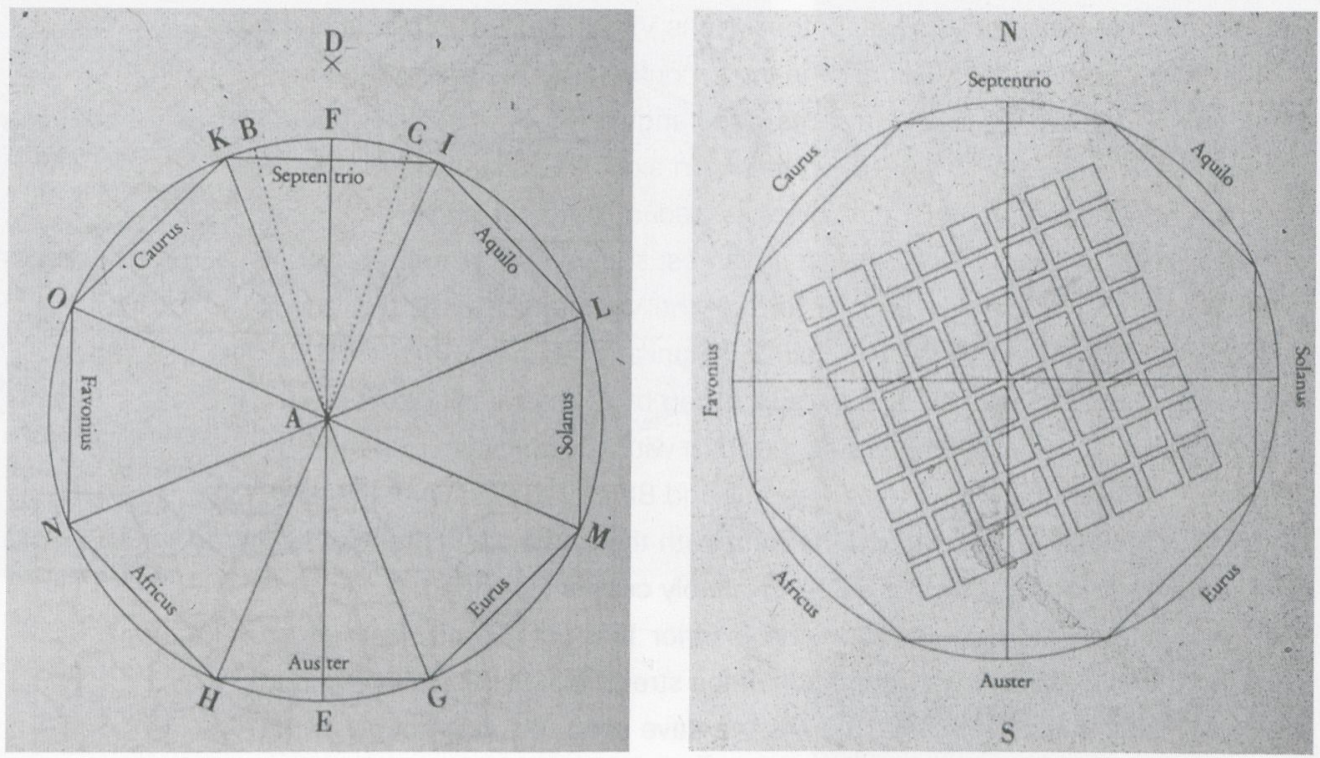

4.1

\section{Modern} reconstruction of the "scheme" of the major winds, according to Vitruvius (Book I, 6, 12): from C. Fensterbusch, Vitruvius, De architectura, Darmstadt 1964, Fig. 3

\section{2}

\section{Modern} reconstruction of the orientation of the city's lanes in relation to the blowing winds, according to Vitruvius (Book I, 6, 7): from C. Fensterbusch, Vitruvius, De architectura, Darmstadt 1964, Fig. 1
Vitruvius's commentators have discussed at length and often criticized his point of view. It is, however, important to evaluate Vitruvius's contribution on his own terms: what at first sight seems to be the product of unpretentious and sometimes even superficial common sense, reveals itself as one of the most theoretical parts of the treatise, because the geometrical rationality of his plan has a manifestly ideal character. ${ }^{9}$ If we want to appreciate the cultural implications of the most important point made in the sixth chapter of the first book - the relationship between micro- and macrocosm implied by the geometrical rationality of the octagon - we must also take into account the crucial second paragraph of the fifth chapter. Here Vitruvius writes: "conlocanda autem oppida sunt non quadrata nec procurrentibus angulis, sed circuitionibus [emphasis mine], uti hostis ex pluribus locis conspiciatur."10 That is, in my own translation: "Fortified towns should neither be built in the form of a square nor with protruding corners; on the contrary, they should be circular [or centrally planned], so that one can control the enemy from many different places."

The word circuitio has created many problems for Vitruvius's commentators, but Gabriele Morolli is convinced that this term, which he associates uncompromisingly with a circular shape, can only signify a centrally planned - and not necessarily fortified - city. Moreover, he thinks that the word oppidum not only refers to a fortified town, but also, in Vitruvius's flexible language, to an (ideal), centrally planned and possibly circular city. ${ }^{11}$ It is true that Francois-Auguste Choisy's 1909 philological edition of the treatise had come to the conclusion that it was impossible to interpret Vitruvius's text on this point, ${ }^{12}$ but Renaissance and post-Renaissance commentators made every 
possible effort to visualize the exterior form of the Vitruvian city (Figures 4.3 and 4.4): for example, Palladio's illustration in the second edition of Daniele Barbaro's commentary (Venice, 1567) represents a rectangular forum inside an octagonal perimeter with circular towers on the main axes, thus clarifying further or even radically changing the opinion expressed in the first edition (Venice, 1556), in which the city was based on an almost square plan surrounded by a fortified hexagon. ${ }^{13}$ The pure circular form of the Vitruvian city was first advocated in the commentary written by Quirico Viviani and Vincenzo Tuzzi in 183032 , but the proposals with eight sides suggested by Barbaro-Palladio, Giovanni Antonio Rusconi, and Claude Perrault, the form with sixteen sides preferred by Cesare Cesariano, Giovanni Battista Caporali and Berardo Galiani in the second edition of his treatise in 1790, and the form with thirty-two sides proposed by Joseph Francisco Ortiz y Sanz were all invariably centrally planned. ${ }^{14}$

Vitruvius's comments on the exterior form of the city cannot be separated, however, from the orientation of the streets inside the walls. The two problems are intrinsically connected. As we have seen, the orientation of the streets of his city is determined ex negativo by the directions of the winds: since the orientation of the lanes should be rotated obliquely to the celestial regions, it follows that they must be placed at a right angle to the main north-south and east-west axes of the earth. The banality of this move, which was partly based on inaccurate physiological assumptions, must have baffled the commentators of Vitruvius's text, so that the majority of them remain mute on this point. This apparently simple operation, however, implies a vision of an ideal city, since Vitruvius knew that his scheme of the winds was an abstraction and a simplification. To summarize what he writes in the ninth paragraph of the sixth book: those who know many names of winds will perhaps marvel at the fact that I (Vitruvius) have listed only eight of them - thus following the model of the tower of the winds built by Andronicus in Athens. The reality is that each of the eight parts of the circumference of the terrestrial globe embraces, according to the calculations made by Eratosthenes, a very large measure, and it is therefore not surprising "that in so large an expanse a single wind's wandering, twisting, and receding should create varieties by shifting its breath." ${ }^{15}$ Furthermore, Vitruvius knows the phenomenon of morning breezes as well as the irregular movements of some winds which blow only during certain seasons of the year, as paragraphs ten and eleven of the same book reveal (Figure 4.5). And in the same passage he describes a wind-rose with twenty-four winds. ${ }^{16}$

Vitruvius was, thus, aware of the complexity of the real world and this means that, when he discussed in his treatise the construction of the city walls and the orientation of its streets according to the regions of the heavens, he provided us with something more than pragmatic instructions about how to avoid the effects of noxious sublunary air-drafts in the planning of a real city. His elegant geometrical scheme was not only the result of (erroneous) 

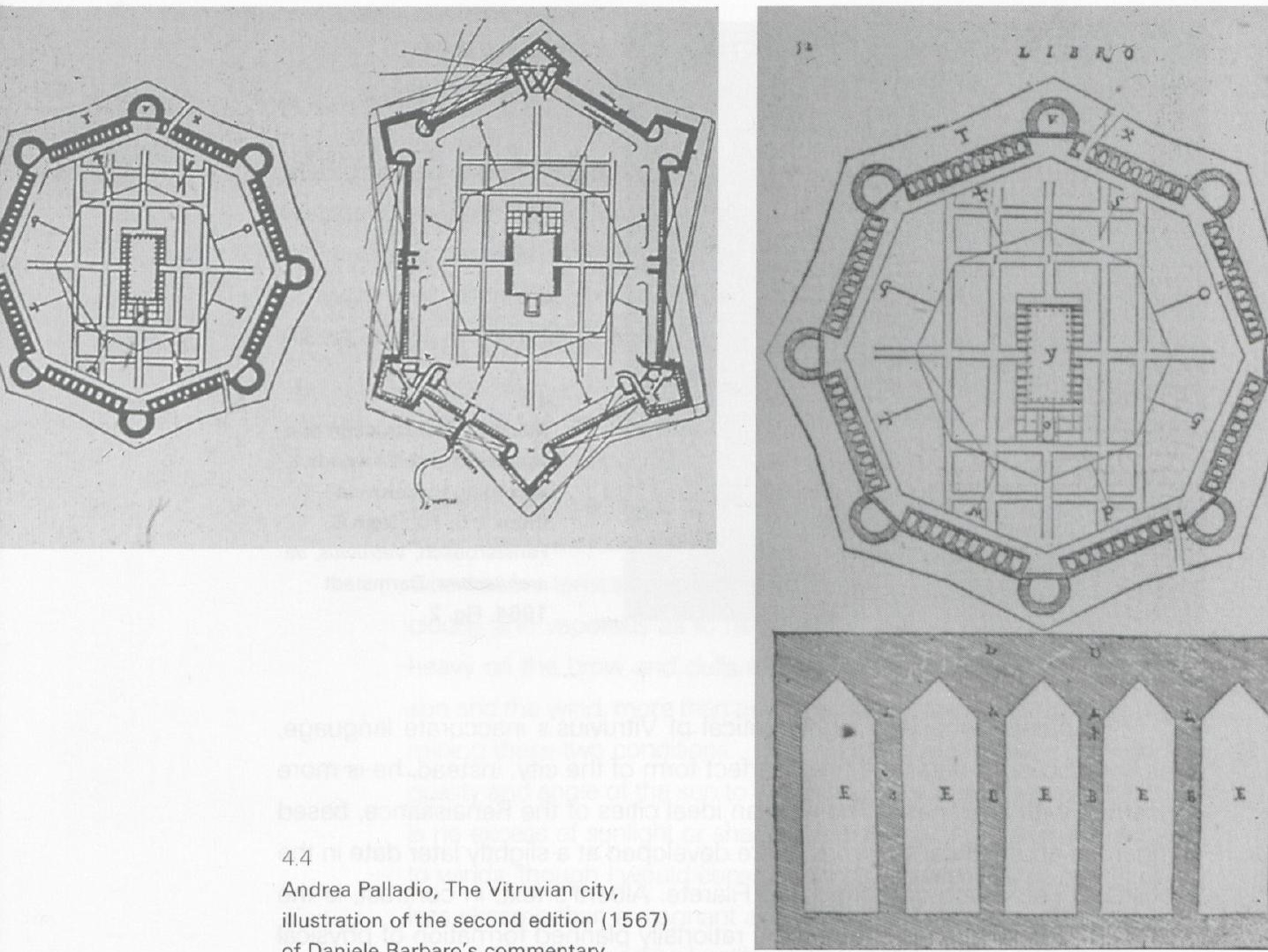

4.4

Andrea Palladio, The Vitruvian city, illustration of the second edition (1567) of Daniele Barbaro's commentary.

practical - physiological - considerations, but also an attempt to allow the harmony of the universe to dominate the chaos of everyday life. The turbulence of the winds should be kept out in order to reproduce the harmony of the higher spheres.

The most recent commentators on Vitruvius's treatise have frequently exposed the vulnerability of the architect's implausible theory of the winds as harmful agents. As early as 1830-32 Quirico Viviani pointed out, for example, that modern science had demonstrated that not all winds are noxious, ${ }^{17}$ a point Alberti had already made. ${ }^{18}$ Viviani concluded that the most reasonable advice to the architect was that of planning straight lanes in correspondence with healthy air-drafts and winding streets where harmful winds blow. Such commentators have failed, however, to understand that Vitruvius was aware of his scheme's abstraction. It is exactly because the phenomenological world was more complex than his theory of the eight regular winds - just as the building of real cities did not conform to his ideal plan - that the geometrical harmony of his urban model can be also interpreted as a partly utopian proposal for an ideal, centrally planned city which should reflect the harmony of the universe's superior spheres. 


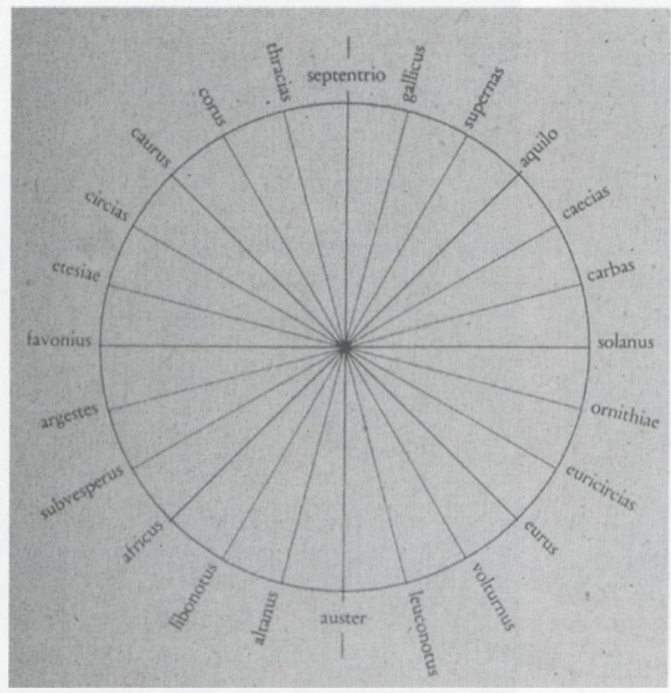

4.5

Modern reconstruction of a wind-rose with 24 winds, according to Vitruvius (Book I, 6, 10): from C. Fensterbusch, Vetruvius, de architectura, Darmstadt 1964, Fig. 2

Alberti, who was highly critical of Vitruvius's inaccurate language, does not discuss in detail the final, perfect form of the city; instead, he is more concerned with its genesis. The utopian ideal cities of the Renaissance, based on rigorous geometrical schemes, were developed at a slightly later date in the treatises of Francesco di Giorgio and Filarete. Alberti's text, in contrast, is the product of a new science, namely the rationally planned formation of physical as well as social urban spaces. The difference between Alberti and Vitruvius is reflected in the very titles of their theoretical works: Alberti's res aedificatoria does not convey the same complex of issues implied by Vitruvius's architectura. $^{19}$ In Vitruvius, a highly practical approach to the problems of building is combined with an interest in the order of the universe. Alberti's treatise is, instead, the result of a typically humanistic project: human reason masters the irrational furor of nature and its elements, since their taming is the premise for the well-regulated life of a civilized community. ${ }^{20}$ It is in this context that Alberti's discussion of the role played by air and winds in the foundation of the city in the first book and in the plan of a magnificent urban structure described in the fourth book must be interpreted.

In the second chapter of the fourth book Alberti writes:

We ... should project a [magnificent] city by way of example. ... It is particularly important to determine whether to locate your city in an open plain, on the coast, or in the mountains: each has advantages and disadvantages. ... Whenever a city must be sited in the mountains, ... make sure that when the winds, especially Boreas, are excessive and troublesome, they do not cause too much damage: 
since it is Boreas, according to Hesiod, that leaves everyone (the old in particular) torpid and hunchbacked. ${ }^{21}$

Medicine and the effects of the climate upon human life as well as upon the weathering of architectural materials play a greater role in Alberti's treatise than in Vitruvius's, and this is the reason why his discussion of the winds has more to do with their effects upon health than on the orientation of the city's lanes. Alberti writes in the third chapter of the first book:

Certainly the air that we breathe, ... when really pure, may have an extraordinarily beneficial effect on health.... It is quite apparent that the healthiest form of air is that which is the purest and least polluted, the most easily pierced by the sight, the most transparent and light ... whereas we term as pestilential any form of air whose consistency is so cloudy and vaporous as to render it dense and fetid, so that it hangs heavy on the brow and dulls that keenness of sight. I believe that the sun and the wind, more than any other factor, are responsible for determining these two conditions.... It is no bad thing, then, to consider the quality and angle of the sun to which a locality is exposed, so that there is no excess of sunlight or shade.... Personally, I prefer gentle breezes to winds, though I would consider winds, however fierce and blustery. less irksome than a stagnant and heavy atmosphere.... The winds ... cannot be all classed as healthy or unhealthy of their nature. ${ }^{22}$

Vitruvius had also discussed at length the choice of a salubrious site for his city, but his text was an organic premise associated with the construction of the walls, the orientation of the streets and the allocation of the public spaces. Alberti does not develop his argument in this direction, but rather moves on to discuss the problems of water, area, subdivision, walls, roofs and openings - regio, area, partitio, paries, tectum, apertio - before turning to the materials of architecture in the second book of his treatise. The winds, therefore, do not play a major role in the distribution of the lots inside the Albertian settlement; nor do they contribute significantly to the image of the "magnificent" city alluded to in the fourth book.

In this matter only a few excerpts of his treatise seem to have been indirectly influenced by Vitruvius: in the first of these passages Alberti explains how to orient the walls of a polygonal building, so that its angles are not damaged by the violence of natural phenomena, and in the others he analyzes the best way to orient the windows of a palace or a villa according to the directions of the most important winds. The first quotation reads:

The angles ought to be positioned counter to the pressure of rocks or the likely direction of violent water and winds, so as to divide and 
dissipate the destructive blows as they strike, by facing the trouble with the strongest part of the wall rather than the weakness of a side. ${ }^{23}$

In a sense this passage seems to imply that the streets should be placed obliquely to the directions of the winds, thus following Vitruvius's instructions. But Alberti speaks pragmatically of one single building and not of the orientation of the city's lanes. Furthermore, there is no trace of a connection between the universe with its cardinal points and the city of man in which the streets can be either straight or winding according to its type.

As far as the passages on the placing of the openings in palaces and villas are concerned, they follow the requirements of practical common sense. The problem of the air is related to that of good illumination because they both contribute to create a healthy environment. Alberti does not offer fixed rules, as Vitruvius does, precisely because they would be abstract suggestions. In this sense, Alberti is not particularly interested in an ideal, immutable model, even if he mentions an exemplary magnificent city in the fourth book; his principal goal instead is to give down-to-earth advice for all possible situations. His "ideal" city is a real city which is designed according to the rational laws of a new urban science. In consequence. Alberti's instructions in the matter of winds are also pragmatic and flexible.

The difference between Vitruvius's and Alberti's approaches to this problem is finally confirmed by their different positions vis-à-vis the architect's need for a knowledge of astronomy. Whereas Vitruvius is convinced, in accordance with his micro-macrocosm vision, that the architect should be well versed in all aspects of astronomy, ${ }^{24}$ Alberti appears to be less demanding. In the tenth chapter of the ninth book he seems to criticize Vitruvius when he writes that it is ridiculous to expect, as some say,

that an architect ought to be an expert in law... Nor do I demand that he should have an exact understanding of the stars, simply because it is best to make libraries face Boreas, and baths the setting sun... It is enough that he does not build on public land, or on another person's property; ... [and] that he has a sound knowledge of the winds, their directions, and their names. ${ }^{25}$

Alberti's lucid unpretentiousness and moderation are a far cry from Vitruvius's ambitious aims and, at times, confused language. Their treatises belong to two different literary genres and differ on the fundamental concepts of the discipline of architecture as well as in matters of principle. Vitruvius's architectura is the practice of building which reflects the harmony of the universe. Alberti's res aedificatoria aims at the foundation of a new functional architecture in the service of the State, and the State manifests itself visually in the form of the 

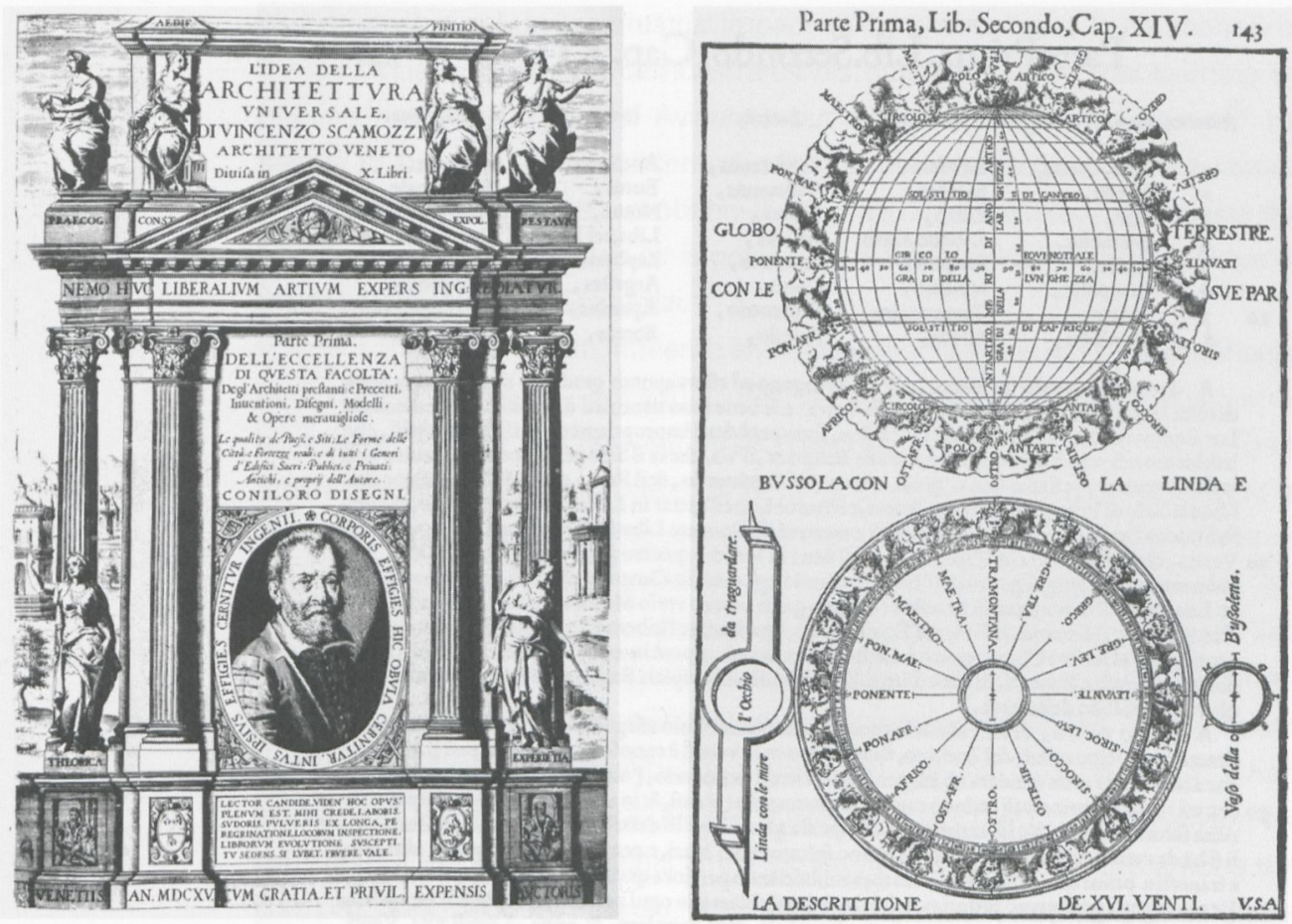

4.6

Vincenzo

Scamozzi, L'idea della architettura universale, Venice 1615, Frontispiece

4.7

The globe and its hemispheres:

Vincenzo

Scamozzi, L'idea della architettura universale, Venice 1615 , p. 96 city. For Alberti, therefore, the city is not only a stone and brick construction, but also a political and historical entity. We have already said that Alberti was not particularly concerned with the final or perfect form of one ideal city. For him it was more important that its structure reflected its social and political order. ${ }^{26}$ The city of the Florentine oligarchy could in theory be the best model, but it was only one of many possible alternatives. The essential point, however, is that his treatise invented "town-planning" as an accepted humanistic discipline, ${ }^{27}$ and in this perspective the winds were more important for their effects upon health and architectural materials than for their possible cosmological connotations.

The second book of Vincenzo Scamozzi's L'idea della architettura universale, published at the author's expense in Venice in 1615, deals almost exclusively with geography, the climate, the choice of healthy sites, the foundation of cities, and natural phenomena like water, air and the winds (Figures 4.6, 4.7). His themes are not very different from those addressed by Vitruvius and Alberti in their introductory books and, indeed, Scamozzi does not add significantly to the conclusions arrived at by his predecessors. Yet one is overwhelmed by the encyclopedic exhaustiveness of his erudition. In 122 pages in quarto he lists and comments upon all imaginable sources; furthermore, if his detailed empirical knowledge is sometimes weighed down by his pedantic digressions, it has to be admitted that it is often more accurate than the 


\section{Parte Prima, Lib.Secondo, Cap. XIV.}

Numero, Nomi de' Naviganti, Italianti,

Eite, Olefte,
Suefte,
Sur,
Suduefte,
Oefte,
Noroeite,
Norte,
Nordefte,

Leuante,

Siroceo,

Oftro,

Ponente,

Maeftro,
Tramontana,

Greco,

\author{
Latini,
}

Libecio,Garb.

I
Subfolanus,

Vulturnus,

Aufter,

Africus,

Fauonitus,

Corus,

Septentrio,

Aquilo,
Greci,

Apeliotes,

Eurus;

Notus,

Libs, vel Lips,

Zephyrus,

Argeites,

Apartias,

Boreas;
Sitwatione.

Laterale.

Ortogonale.

Polare antartico.

Ortogonale

Laterale.

Ortogonale.

Polarearticale.

Ortogonale.

A २ у в 3 т 0 modo tra Vento, e Vento vengono ad effere apunto gradi vL. ched l'ortaua parte di turta la circonferenza del Cielo, e della Terra : e fe bene fono nominati da molti hor Cardinali, \& hor Equinottiali , \& talhor Vernali, \& Eftiui, fono peròdetti impropriamente : rifpetto à quelli, che habbitano nel vero Equinortio, e fotto alla Ecliptica, ò via, che fa il Sole per il Zodiaco, enon à noi, quì in Venetia, che fiamo in 45. gradi apunto trà l'Equinottio, \& il Polo, oue il Sole nel tempo del. P'Equinottio di Primauera, entra in Ariete,e d'Autunno nell'entrar in Libra lieua tre gradi emezo ver. fo Sirocco Leuante, e Tramonta tre gradi e mezo verfo Ponente Libecio. Poine' piü curti giorni del 20 Verna, che il Sole entra in Capricorno, egli lieua in Sirocco quattro gradi verfo Oltro Libecio, efinalmente ne' più lunghi giorni dell'Eftate, quando cgli entra in Cancro otto gradi e mezo verfo Gre. co Leuante, e Tramontana in Maeftro : mì otto gradi c mezo verfo Maeftro Ponente. Perche come fi.2.6.46. dice Srrabone il Leuante, e Ponente Equinuttiale, e parimentel'hiberno, el'eftiuo s'intendono fempre rif́petto al noftro Clima, ouero à quello d'altri popoli, e però in tutto il tempo dell'anno fi fanno

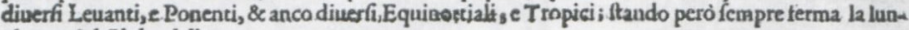
ghezza del Globo della terra.

A a I 5 T O I E L E, \& altri che lo feguono, come anco Plinio affegnarono XI I. Venti corrifpon- lis.c.47 dentra $x 1$ x. Fegniseleftidel Zodiaco, ilqual numern in vero fi è conofciutob che non può ftare si perchenon fi confia nelta maniera ch' effi penfano a' circoli del mondo, (come moftraremo) fi ancora per-

30 che trà i quattro principali cadono ragioncuolmente altri Venti, $\&$ in altro fito: effendoche per elperiéza farta da marinari (e fpecialmente daffi quefta glorià cuelli della Città d'Arano in Fiädra)̀̇ qualifi hà da creder molto, come quelli, c'hanno folcato turti Mari, e però ne furono aggiunti altri otto, e frapofti a primi otto, $i$ quali fi dicono mezanj;lafciando per hora quelle minutie dell equarte trà ogni Vento, lequali aon hanno propri nomi,\& i marinarichiamano ogni parte Rombo; quafi cheogn' una faccia nella Boffola da nauiganti vna figura Rombale, ciò̀ angolare, \& acuta. I quali xv v. Venti incominciando done lieua il Sole, e feguendo in giro tengono queltoordine.

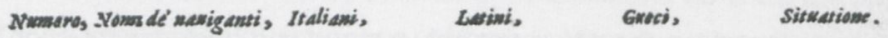

40

2 Ooft,

- Ooft Zuyd Ooft,

3 Zuyd Ooft,

Zuyd Zuyd Ooft.

Zuydt,

Zuyd zuyd Vveft,

Zuyd Vveft,

Vveft Zuyd Vveft, Ponente Libec.

Vveft,

Leuante,

Subfolanus,

Sirocco Leuante, Omitia aliq.

Siroceo,

Oftro Sirocco,

Vulturaus,

Phoenitias Leuc.

Oftro,

Aufter,

Africus, Carbas,

Subuefperus
Fauonius,

Ponente,

Fauonius,

Caurus, Corus,

Io Vveft Noort
II Noort Vveft, Noort Vveft, Maeftro,

Circius,

13 Nowrt, Maeftro Tram.

Septentrio,

Tramontana,

Noort Noort Ooft,

Noort Ooft,

16 Ooft Noort Ooft,
Greco, Aquilo,
Greco Leuante, Hellefpontia,
Apeliotes,

Ornitias,

Eurus, Sciron. Ortogonale.

Euronotus, Mezano.

Libonotos,

Libs,ò Lips,

.....

Zephyrus,

Erefias,

Argeftes,'

Thracias,

Apartias,

.....

Boreas,

Cxcias,
Cardin.laterale.

Mezano.

Polare antarticale.

Mezano.

Ortogonale.

Mezano.

Cardinale later.

Mezano.

Ortogonale.

Mezano.

Polare articale.

Mezano.

Ortogonale.

Mezano.

- 3 E $28 x$
4.8

Vincenzo

Scamozzi, L'idea

della architettura

universale, Venice

1615, p. 141

observations made by either Vitruvius or Alberti - not least because it is the product of a new age which was better informed about the world in which we live. ${ }^{28}$ I will be discussing only a few points in order to highlight Scamozzi's original contributions to the history of the wind and the city.

The, at times unclear, twelfth chapter is dedicated to the nature, quality and variety of the air. In opposition to Vitruvius and Alberti, Scamozzi is explicitly not interested in the phenomenon as one of the elements of natural 
philosophy but only in its terrestrial impact on the environment. In his analysis of the air's quality Scamozzi demonstrates his outstanding medical learning by quoting not only Galen and Avicenna but also the School of Salerno. ${ }^{29} \mathrm{He}$ seems to be exclusively concerned with the practical aspects of the natural phenomenon, and yet he is probably the first architectural theorist to praise the moral quality of the air. Pure air is good for the body as well as for the virtue of the soul, according to Scamozzi. ${ }^{30}$

The fourteenth, fifteenth and sixteenth chapters are then specifically dedicated to the winds - for a total of fifteen pages in quarto. It is in this part of his treatise that we find new information and his most original thoughts. Again Scamozzi does not want to discuss what wind is nor its origin because that is the concern of natural philosophers. ${ }^{31}$ What characterizes his approach at its best is instead his preoccupation with practical details, together with his modern critique of such ancient authorities as Vitruvius and Aristotle. To the first category belong the following observations. The study of the winds is of fundamental importance for the architect not only because it allows him to orient buildings and their parts with good judgment, as Vitruvius and Alberti had already argued, but also because the builder should know the right season for carrying out the final ornaments of the structure. ${ }^{32}$ Scamozzi is also among the first, probably following Palladio, ${ }^{33}$ to comment upon the ventidotti or air channels which, in the summer season, served to transport fresh breezes from the quarries around Vicenza to the rooms of the surrounding villas in Costozza and Brendola. ${ }^{34}$ Finally, for all that Vitruvius and Alberti had already discussed the relationship between the directions of the winds and the different functions of rooms, Scamozzi's information is much more detailed.

Alberti had written, for instance, that studies, workshops and summer dwellings should be oriented to the north, winter apartments to the south, and all those for spring and autumn to the east. Baths and supper parlors for the spring season should be erected in the west part of the building. These rather generic instructions are dealt with in greater detail by Scamozzi, who relies more on Vitruvius and partly changes Alberti's orientation. Studies and libraries should not face the north, as Alberti had suggested, but the east, where one also finds the drawing rooms. Summer apartments, workshops, wine cellars and barns should be oriented to the north. Baths belong to the west side. The southern winds bring mostly negative effects: we should therefore avoid planting open gardens on this side, which is good only for the conservation of oils. ${ }^{35}$

Scamozzi's discussion of this matter is lucid and simple because he is convinced that his profession can improve the quality of our life on this earth, and that the architect can make his fellow-citizens happier. ${ }^{36}$ His flexibility and lack of prejudice make him the perfect exponent of a new age. The cities indicated as models are no longer a Roman settlement or a Tuscan town. Scamozzi says instead that the air of an urban space must be temperate and that the city. 
therefore, must be founded in a free and open space like Amsterdam or Venice. ${ }^{37}$ The orientation of the streets remains linked to the directions of the healthy and harmful winds, but the climates of Hungary, Poland and Germany require different solutions from those adopted in Italy. ${ }^{38}$ This means that a well-planned city must take into account a given set of circumstances; a universal model therefore makes little sense.

Scamozzi's geographical perspective is, for historical reasons, wider ranging than that of his predecessors. And at the beginning of the second book of his treatise he is not afraid to say that Aristotle was wrong on many issues. In his discussion of the circular extension and circumnavigation of the earth Scamozzi writes:

Even if Aristotle made fun of the opinion... that one could circumnavigate the earth... this has been done on numerous occasions by sailors who have been to the New World and have travelled in the direction of the poles: in America our ancestors discovered many notable kingdoms and provinces. [They] also [discovered that it is possible] to live comfortably south of the equator, all things that contradict the opinion of the same Aristotle. ${ }^{39}$

Scamozzi's text is the product of new knowledge and of a new mentality. He is very proud of his independence of judgment. Scamozzi questioned the view of the natural world inherited from the antique sources and, in his description of the wind-rose, he did not refrain from rebutting the accepted wisdom by citing as his source the practice of the Dutch seamen who are more reliable and therefore more competent than Aristotle. Scamozzi writes:

As far as the number of the winds is concerned, opinions differ among the ancients, even if according to Homer... only two of them were famous, namely the Ostro [i.e. Auster, the south wind] and the Tramontana [the north wind]... Vitruvius, Pliny and many others, however, gave four names to the four parts or, as people say, points of the compass.... In astronomical and cosmographical terms, this means that they are separated from each other by $90^{\circ}$ on the entire $360^{\circ}$ circuit of the sky and of the earth, so that each of them occupies a quarter of the circumference, of this machine we call the world. The Greeks then... developed with great artifice [a scheme] with eight winds, [as one can see] on the Tower [of the winds] in Athens.

At the top of page 141 Scamozzi gives a list of the orientations and names of the eight principal winds in Greek, Latin, Italian and Spanish. The quotation continues: 
Aristotle and others who follow his opinion... developed [a scheme] with twelve winds which correspond to the twelve signs of the zodiac: this number cannot be right, however, both because it is now recognized that one cannot count in the way they think one should... and because one can reasonably suppose that many other winds exist between the four principal winds and elsewhere. That they are free to occupy other spaces is confirmed by the practical experience of sailors (particularly those who bring glory to the city of Arano in Flanders), to whom credence must be given since they have traversed the oceans. And this is the reason why eight other winds have been added, and inserted between the other eight: these winds are known as middle-winds... These sixteen winds are listed here according to the following order, beginning from where the sun rises and moving clockwise. ${ }^{40}$

At the bottom of the same page Scamozzi lists the orientations and the names of the sixteen winds in Greek, Latin, Italian and Dutch. It is this detailed knowledge of the physical world that inspires his pragmatic and empirical approach to architecture as well as the flexibility of his solutions in his chapters on the origin, foundation and appropriate dimensions of cities. ${ }^{41}$

Scamozzi's theory, or better theorica, to use his own word, has no place for the Vitruvian preoccupation with the correspondence between microand macrocosm. And Alberti's humanistic ideal is also alien to his interests. He does not produce an institutional treatise for the political needs of a powerful emperor, as Vitruvius had done for Augustus, nor does he intend to fulfill the ambitions of an oligarchy which perceived itself as the State and had found in Leon Battista Alberti its theorist, not to say its propagandist. Scamozzi can perhaps be described as a technocrat, instead, even if this term is probably inadequate. In any case he was convinced of the superior knowledge of his society, and his practical competence reflected a new world view. The precise mathematical calculation of parallels and meridians in his text, as well as the corresponding representation of the globe, indicate his more demanding approach to the complexity of the physical world. Yet the theory of the principal winds continued to play a major role in architectural history not only in the reception of Vitruvius's treatise, but also in the foundation of the cities of the New World - as documented by the 1573 urban law promulgated by Philip II. ${ }^{42}$ It also found its place in utopian visions such as that expounded in Tommaso Campanella's Civitas Solis: in this text the ideal city has four main streets linked with four principal gates, which are oriented according to the four points of the compass. ${ }^{43}$ Thus the ideal character of the Vitruvian vision continued to coexist with Scamozzi's Galileian approach. 


\section{Notes}

1 My sincerest thanks to Matteo Burioni for his bibliographical research and David Ekserdjian for improving my English text. Carlo Ginzburg - my warmest thanks to him as well - has added an important reference to the negative reception of Aristotle in the sixteenth century: see note 39.

2 See Blumenberg, Hans, Schiffbruch mit Zuschauer. Paradigma einer Daseinsmetapher. Frankfurt am Main: Suhrkamp Verlag 1979.

3 See Obrist, Barbara, 'Wind Diagrams and Medieval Cosmology'. Speculum 72 (1997), pp. 33-84.

4 Aristoteles, Meteorologie. Über die Welt, ed Hans Strohm, Darmstadt: Wissenschaftliche Buchgesellschaft [1970] 1984, Book I, Chapter 13, 349a, pp. 30-31 and Book II, Chapters 4-6. 359b-365a, pp. 52-63: for the commentary see pp. 179-183.

5 Cesariano, Cesare, De Lucio Vitruvio Pollione de Architectura libri decem traducti de Latino in Vulgare raffigurati, commentati, Como 1521, Bruschi, A., Cargo, A. and Fiore, F.P. (eds), Vitruvio. De Architectura translato commentato et affigurato da Caesare Caesariano 1521. Milano: Edizioni II Polifilo 1981, pp. xxii verso - xxviii verso.

6 Barbaro, Daniele, I dieci libri dell'architettura di $M$. Vitruvio tradutti e commentati da Monsignor Barbaro, 2nd ed., Venice 1567, Book I, Chapter 6, facsimile, Rome: Bardi Editore 1993, pp. 5464. On Barbaro's philosophical sources see Mitrovic. Branko, 'Paduan Aristotelianism and Daniele Barbaro's Commentary on Vitruvius' De Architectura', Sixteenth Century Journal 29 (1998), pp. 667-688.

7 Vitruvius, Ten Books on Architecture, Translation by Ingrid D. Rowland. Commentary and Illustrations by Thomas Noble Howe with additional commentary by Ingrid D. Rowland and Michael J. Dewar, Cambridge: Cambridge University Press 1999, pp. 29-30: Book I. Chapter 6: Orientation.

8 On this point I follow the interpretation of Gabriele Morolli and not the modern English translation: Morolli, Gabriele, 'Vitruvio e la città dei venti regolari. Istituzioni e invenzioni della forma urbana nel De Architectura e nell'esegesi degli interpreti classicistici del trattato', in: Cresti, C., Fara, A. and Lamberini, D. (eds). Architettura militare nell'Europa del XVI secolo (Atti del Convegno di Studi, Firenze, 25-28 Novembre 1986), Siena: Edizioni Periccioli 1988, pp. 299333, above all p. 309.

9 Morolli, Gabriele, Vitruvio e la città dei venti regolari. Istituzioni e invenzioni della forma urbana nel De Architectura e nell'esegesi degli interpreti classicistici del trattato', in: Cresti, C.. Fara, A. and Lamberini, D. (eds), Architettura militare nel/'Europa del XVI secolo (Atti del Convegno di Studi, Firenze, 25-28 Novembre 1986). Siena: Edizioni Periccioli 1988, pp. 306-7, who insists on the ideal character of Vitruvius's city.

10 Morolli, Gabriele, 'Vitruvio e la città dei venti regolari. Istituzioni e invenzioni della forma urbana nel De Architectura e nell'esegesi degli interpreti classicistici del trattato', in: Cresti, C., Fara, A. and Lamberini, D. (eds), Architettura militare nell'Europa del XVI secolo (Atti del Convegno di Studi, Firenze, 25-28 Novembre 1986), Siena: Edizioni Periccioli 1988, p. 301.

11 Morolli, Gabriele, 'Vitruvio e la città dei venti regolari. Istituzioni e invenzioni della forma urbana nel De Architectura e nell'esegesi degli interpreti classicistici del trattato', in: Cresti, C., Fara, A. and Lamberini, D. (eds), Architettura militare nell'Europa del XVI secolo (Atti del Convegno di Studi, Firenze, 25-28 Novembre 1986), Siena: Edizioni Periccioli 1988, pp. 301-2.

12 Choisy, Francois-Auguste, Vitruv. Analyse, Paris 1909, Vol. IV, PI. 4, Figures 1 and 2.

13 Morolli, Gabriele, 'Vitruvio e la città dei venti regolari. Istituzioni e invenzioni della forma urbana nel De Architectura e nell'esegesi degli interpreti classicistici del trattato', in: Cresti, C., Fara, A. and Lamberini, D. (eds), Architettura militare nell'Europa del XVI secolo (Atti del Convegno di Studi, Firenze, 25-28 Novembre 1986), Siena: Edizioni Periccioli 1988, p. 327, note 29.

14 Morolli, Gabriele. 'Vitruvio e la città dei venti regolari. Istituzioni e invenzioni della forma urbana nel De Architectura e nell'esegesi degli interpreti classicistici del trattato', in: Cresti, C., Fara, A. and Lamberini, D. (eds), Architettura militare nell'Europa del XVI secolo (Atti del Convegno di 
Studi, Firenze, 25-28 Novembre 1986), Siena: Edizioni Periccioli 1988, pp. 303-4 and 328, note 45 .

15 Vitruvius, Ten Books on Architecture, Translation by Ingrid D. Rowland. Commentary and Illustrations by Thomas Noble Howe with additional commentary by Ingrid D. Rowland and Michael J. Dewar, Cambridge: Cambridge University Press 1999, p. 30.

16 Vitruvius, Ten Books on Architecture. Translation by Ingrid D. Rowland. Commentary and Illustrations by Thomas Noble Howe with additional commentary by Ingrid D. Rowland and Michael J. Dewar, Cambridge: Cambridge University Press 1999, pp. 30-1.

17 Viviani, Quirico and Tuzzi, Vincenzo, L'Architettura di Vitruvio tradotta in italiano, illustrata con note critiche ed ampliata di aggiunte intorno ad ogni genere di architettura antica e moderna. con tavole incise, Udine 1830-2, p. 105 (Book I).

18 Alberti, Leon Battista, L'architettura, Traduzione di Giovanni Orlandi. Introduzione e note di Paolo Portoghesi, Milan: Edizioni II Polifilo 1989, p. 212: Book V. Chapter 14.

19 A comment made by Argan, Giulio Carlo, 'II trattato De re aedificatoria', in: Convegno Internazionale indetto nel $V$ centenario di Leon Battista Alberti (Roma-Mantova-Firenze, 25-29 aprile 1972), Rome: Accademia Nazionale dei Lincei 1974, pp. 43-54, above all p. 44. On the terminological implications of De re aedificatoria see Choay, Francoise, 'De re aedificatoria als Metapher einer Disziplin', in Forster K.W. and Locher, H. (eds). Theorie der Praxis. Leon Battista Alberti als Humanist und Theoretiker der bildenden Künste, Berlin: Akademie Verlag 1999, pp. 217-31.

20 Argan, Giulio Carlo, 'II trattato De re aedificatoria', in: Convegno Internazionale indetto ne/ $V$ centenario di Leon Battista Alberti (Roma-Mantova-Firenze, 25-29 aprile 1972), Rome: Accademia Nazionale dei Lincei 1974, p. 54.

21 Alberti, Leon Battista, On the Art of Building in Ten Books, translated by Joseph Rykwert, Neil Leach, and Robert Tavernor, Cambridge (Mass.) and London: The MIT Press 1988, pp. 96-8: Book IV, Chapter 2.

22 Alberti, Leon Battista, On the Art of Building in Ten Books, translated by Joseph Rykwert, Neil Leach, and Robert Tavernor, Cambridge (Mass.) and London: The MIT Press 1988, pp. 9-11: Book I, Chapter 3.

23 Alberti, Leon Battista, On the Art of Building in Ten Books, translated by Joseph Rykwert, Neil Leach, and Robert Tavernor, Cambridge (Mass.) and London: The MIT Press 1988, p. 20: Book I. Chapter 8.

24 Vitruvius, Ten Books on Architecture. Translation by Ingrid D. Rowland. Commentary and Illustrations by Thomas Noble Howe with additional commentary by Ingrid D. Rowland and Michael J. Dewar, Cambridge: Cambridge University Press 1999, p. 23: Book I, Chapter 1.

25 Alberti, Leon Battista, On the Art of Building in Ten Books, translated by Joseph Rykwert, Neil Leach, and Robert Tavernor, Cambridge (Mass.) and London: The MIT Press 1988, p. 317: Book IX, Chapter 10.

26 For these points see Argan, Giulio Carlo, 'Il trattato De re aedificatoria', in: Convegno Internazionale indetto nel V centenario di Leon Battista Alberti (Roma-Mantova-Firenze, 25-29 aprile 1972), Rome: Accademia Nazionale dei Lincei 1974, pp. 52-3.

27 Argan, Giulio Carlo, 'Il trattato De re aedificatoria', in: Convegno Internazionale indetto ne/ V centenario di Leon Battista Alberti (Roma-Mantova-Firenze, 25-29 aprile 1972), Rome: Accademia Nazionale dei Lincei 1974, p. 44.

28 Scamozzi, Vincenzo, Dellidea della architettura universale, Venice 1615, reprint, Ridgewood (NJ): Gregg 1964, pp. 97-218. For an up-to-date bibliography on the architect and his treatise see Barbieri, F. and Beltramini, G. (eds), Vincenzo Scamozzi 1548-1616. Venice: Marsilio editori 2003.

29 Scamozzi, Vincenzo, Dellidea della architettura universale, Venice 1615, reprint, Ridgewood (NJ): Gregg 1964, p. 135.

30 Scamozzi, Vincenzo, Dellidea della architettura universale, Venice 1615, reprint, Ridgewood (NJ): Gregg 1964, p. 133 
31 Scamozzi, Vincenzo. Dellidea della architettura universale, Venice 1615, reprint, Ridgewood (NJ): Gregg 1964, p. 139.

32 Scamozzi, Vincenzo, Dellidea della architettura universale, Venice 1615, reprint, Ridgewood (NJ): Gregg 1964, p. 139.

33 Palladio, Andrea, I quattro libri dell'architettura, Venice 1570: Dominico de' Franceschi, Book I. Chapter 27.

34 Scamozzi, Vincenzo, Dellidea della architettura universale, Venice 1615, reprint, Ridgewood (NJ): Gregg 1964, p. 140.

35 Scamozzi, Vincenzo, Dell'idea della architettura universale, Venice 1615, reprint, Ridgewood (NJ): Gregg 1964, pp. 149-51.

36 Kruft, Hanno-Walter, Geschichte der Architekturtheorie. Von der Antike bis zur Gegenwart. Munich: C.H. Beck 1985, p. 113.

37 Scamozzi, Vincenzo, Dell'idea della architettura universale, Venice 1615, reprint, Ridgewood (NJ): Gregg 1964, p. 159.

38 Scamozzi, Vincenzo. Dellidea della architettura universale, Venice 1615, reprint, Ridgewood (NJ): Gregg 1964, p. 169.

39 Scamozzi, Vincenzo, Dell'idea della architettura universale, Venice 1615, reprint, Ridgewood (NJ): Gregg 1964. p. 99: “Tutto che Aristotele tenesse per cosa ridicola ... che si potesse far la circuitione del Globo della terra ... [questo] si è verificato più volte da' naviganti del Mondo nuovo, e verso i Poli: essendosi scoperto nell'America tanti, e così memorabili Regni, e Provincie a' tempi de' nostri Avi; \& anco I'habitar comodamente sotto all'Equinottiale, tutte cose contra I'opinione del medesimo Aristotele." As Carlo Ginzburg has pointed out to me, the critique of Aristotle's fatuitates in this field is already to be found in a lecture given by the philosopher Pietro Pomponazzi in Padua: his source was Antonio Pigafetta, who had navigated the southern hemisphere. Pomponazzi's words are published in Nardi, Bruno, 'I corsi manoscritti di lezioni e il ritratto di Pietro Pomponazzi', in: Nardi, B., Studi su Pietro Pomponazzi, Florence: Leo S. Olschki 1965, pp. 3-53 and above all pp. 41-4.

40 Scamozzi, Vincenzo, Dellidea della architettura universale, Venice 1615, reprint, Ridgewood (NJ): Gregg 1964, p. 141: “Quanto al numero dei Venti, appresso à gli Antichi fu diverso parere. e con tutto che col testimonio d'Homero [... s siano due soli famosi, cioè Ostro e Tramontana. [...] Con tutto ciò Vitruvio, e Plinio e molti altri ne assegnarono poi quattro alle quattro parti o. come dicono, Cardini del mondo. [...] Onde parlando con termini d'Astrologia e di Cosmografia vengono distanti l'uno dall'altro 90 gradi di 360 di tutto il circuito del Cielo e della Terra, di modo che ogn'uno d'essi viene ad occupare la quarta parte della circonferenza di questa machina del Globo Mondiale. Ma i Greci [ ... ] assegnarono nella Torre d'Athene con molto artificio otto Venti. Aristotele, e altri che lo seguono, [...] assegnarono dodici Venti corrispondenti a dodici segni celesti del Zodiaco, il qual numero invero si è conosciuto che non può stare sì perché non si conta nella maniera ch'essi pensano, [...] sì ancora perché tra i quattro principali cadono ragionevolmente altri Venti, e in altro sito: essendo che esperienza fatta da marinari (e specialmente dassi questa gloria à quelli della Città d'Arano in Fiandra) à quali si hà da creder molto, come quelli c'hanno solcato tutti i Mari, e perciò ne furono aggiunti altri otto, e fraposti ai primi otto, i quali si dicono mezani. [...] I quali sedici venti incominciando dove lieva il Sole e seguendo in giro tengono questo ordine."

41 The same systematic thinking accompanied by the credit given to the experience of the seamen is also characteristic of Francis Bacon's natural philosophy: see Bacon, Francis, Historia Naturalis et Experimentalis de Ventis \& c. Leyden: Apud Franciscum Hackium 1648. 